\title{
THE IMPORTANCE OF SONICATION AND PRE-OPERATIVE ANTIMICROBIAL THERAPY
}

\author{
POMEN SONIKACIJE PRI PREDOPERATIVNI ANTIBIOTIČNI \\ TERAPIJI
}

\author{
Boštjan Kocjančičc*, Andrej Lapoša, Drago Dolinar \\ Department of Orthopaedic Surgery, University Medical Centre Ljubljana, Zaloška cesta 9, 1000 Ljubljana, Slovenia \\ Prejem rokopisa - received: 2019-06-17; sprejem za objavo - accepted for publication: 2019-09-24
}

doi:10.17222/mit.2019.130

\begin{abstract}
The purpose of the study was to evaluate the use of sonication in the detection of prosthetic joint infections with the emphasis on patients who received pre-operative antimicrobial therapy. Consecutive patients that required revision surgery of the hip or knee arthroplasty were enrolled in the study. An algorithm for the diagnosis of prosthetic joint failure based on the culture of intraoperative tissue samples and the sonication of explanted orthopaedic material was used. The results of both methods were compared and evaluated. Between November 2010 and December 2013, 103 patients were enrolled, which underwent 136 revision procedures. In 31 cases $(22.8 \%)$ the patient received pre-operative antimicrobial therapy. Prosthetic joint infection and aseptic failure was diagnosed in $69(50.7 \%)$ and $45(33.1 \%)$ cases. In 22 cases $(16.2 \%)$ microbiology was inconclusive. Sonication was a significantly better diagnostic method for the detection of prosthetic joint infection when pre-operative antimicrobial therapy was received $(\mathrm{p}<0.05)$. In recent years sonication has become vital for the diagnosis of prosthetic joint infection. According to our results, it is especially crucial in patients that received pre-operative antimicrobial therapy.

Keywords: sonication, prosthesis-related infection, antimicrobial therapy, revision
\end{abstract}

Namen študije je bil oceniti uporabo sonikacije za odkrivanje okužb endoprotez, s poudarkom na bolnikih, ki so prejeli predoperativno antibiotično terapijo. V študijo so bili vključeni zaporedni bolniki v obdobju od 1.1.2010 do 31.12.2013, pri katerih smo opravili revizijsko operacijo endoproteze kolka ali kolena. Uporabili smo algoritem za diagnozo okužbe endoproteze sklepa na podlagi mikrobioloških kultur intraoperativnih vzorcev tkiv in ultrazvočne obdelave odstranjenega ortopedskega materiala (sonikacija komponent ali celotnih endoprotez). Rezultate obeh metod smo primerjali in ovrednotili. V zgoraj omenjenem času smo opravili 136 revizijskih postopkov pri 103 bolnikih, ki so bili vključeni v študijo. V 31 primerih $(22,8 \%)$ so bolniki prejeli predoperativno antibiotično zdravljenje. Vzrok za revizijsko operacijo je bila okužba endoproteze sklepa in aseptična odpoved, ki smo ju diagnosticirali pri $69(50,7 \%)$ oziroma $45(33,1 \%)$ primerih. V 22 primerih $(16,2 \%)$ je bila mikrobiološka analiza nezanesljiva. Sonikacija je bila bistveno boljša diagnostična metoda za odkrivanje endoprotetične okužbe sklepov potem, ko je bila izvedena predoperativna antibiotična terapija $(\mathrm{p}<0,05)$. V zadnjih letih je postala sonikacija odstranjenih komponent endoprotez ključna za diagnozo okužbe endoprotetičih sklepov. Naši rezultati kažejo, da je to še posebej pomembno pri bolnikih, ki so prejemali predoperativno antibiotično zdravljenje.

Ključne besede: sonikacija, okužbe endoprotetičnih sklepov, antibotična terapija, revizija

\section{INTRODUCTION}

Accurate differentiation between aseptic failure and infection is a key component in the successful treatment of orthopaedic implant-associated complications. A clear differentiation between the two conditions remains one of the goals of modern orthopaedic surgery. With the ageing population there is a steady increase in the number patients requiring total joint arthroplasty. ${ }^{1}$ Consequently, there is an increase in the number of revision procedures, with $8 \%$ of prostheses requiring revision surgery within 10 years. Approximately $75 \%$ of revision procedures are due to aseptic loosening and $8 \%$ of the cases due to primary or secondary prosthetic joint infections. ${ }^{2}$ The treatment of aseptic loosening differs significantly from the treatment of prosthetic joint infection (PJI), where the therapeutic approach is individualized according to the infection stage, pathogen and patient characteristics. ${ }^{3}$

*Corresponding author's e-mail:

bkocjancic@gmail.com (Boštjan Kocjančič)
The role of biofilm in orthopaedic implant infections has been well established and represents a diagnostic challenge. ${ }^{4}$ Microorganisms in biofilm grow clustered in a highly hydrated extracellular matrix attached to a surface. After an initial phase micro-organisms enter a stationary phase, making them more resistant to antimicrobial therapy and host defences. ${ }^{5}$

In recent years the introduction of the sonication of removed orthopaedic implants has improved the diagnosis of PJI. Since the first report of the use of sonication in the diagnosis of orthopaedic implant infections by Tunney, the method has gained wide approval and is implemented in the diagnostic protocols of the majority of orthopaedic centres. ${ }^{6}$ The method applies ultrasound waves to disrupt biofilm from the surface of materials without affecting the viability of the micro-organisms. ${ }^{7}$ The obtained material can then be further processed using standard or advanced microbiologic techniques.

Sonicate-fluid culture has a higher sensitivity compared to periprosthetic tissue culture $(78.5 \%$ versus $60.8 \%)$, with similar specificities $(98.0 \%$ versus 
$95.1 \%)$. The value of sonication is even greater in cases of pre-operative antimicrobial therapy, where the sensitivity remains high $(75 \%$ versus $45 \%) .{ }^{8}$ Sonication can be further enhanced using polymerase chain reaction (PCR) analysis of the sonicate fluid, which has, compared to the sonicate-fluid culture, additionally improved the sensitivity (78\% versus $62 \%$ ). ${ }^{9}$ In a recent report multiplex PCR of sonicate-fluid has demonstrated a high sensitivity $(96 \%)$ and specificity $(100 \%)$ for the diagnosis of PJI. ${ }^{10}$

Since the introduction of sonication, aseptic loosening has in many cases been proven to be clinically silent PJI. ${ }^{11}$ It is believed that $4-13 \%$ of patients with a preoperative diagnosis of aseptic loosening have culturenegative PJI. ${ }^{12,13}$ In patients treated for aseptic loosening with marked osteolysis and negative periprosthetic tissue cultures, the sonicate-fluid cultures were positive in $57 \%$ of patients. ${ }^{14}$

There is still no clear consensus on the diagnostic criteria for PJI. ${ }^{15,16}$ According to the latest recommendations, the diagnosis is based on clinical status, isolation of pathogen, laboratory parameters, cell count of synovial fluid and histologic analysis of periprosthetic tissue. Although the use of sonication is rapidly growing, it has not yet been widely implemented in the guidelines of prosthetic joint infection detection and is only recommended in doubtful cases. ${ }^{17}$

The purpose of our study was to evaluate the use of sonicate-fluid cultures and periprosthetic tissue culture for the detection of prosthetic joint infections. The study was directed towards the assessment of the impact of pre-operative antimicrobial therapy on the accuracy of the methods. Furthermore, we wanted to evaluate ideal cut-off values of pre-operative C-reactive protein (CRP) concentration and erythrocyte sedimentation rate (ESR) in cases of aseptic loosening and PJI using ROC analysis.

\section{METHODS}

\subsection{Study population}

In a level II diagnostic study consecutive patients admitted to the Department of Orthopaedic Surgery of the University Medical Centre, Ljubljana, Slovenia for revision surgery of hip or knee arthroplasty, were invited to participate. Patients were excluded from the study if there was inadequate number of tissue samples sent to the microbiological laboratory for culture or if there were signs of comorbidities, which alter the systemic inflammatory response. The study was approved by the Republic of Slovenia National Medical Ethics Committee (No. 93/02/13).

\subsection{Pre-operative and peri-operative procedures}

Pre-operatively, the patients were examined for the presence of local signs of infection, plasma concentration of C-reactive protein (CRP) and erythrocyte sedimentation rate (ESR). Pre-operative antimicrobial therapy was defined if any antimicrobial therapy was given for $\geq 24$ hours within 14 days prior to revision surgery. After careful pre-operative planning according to the accepted algorithm for the treatment of aseptic loosening or PJI revision surgery followed. During the surgical procedure, 2-5 samples of periprosthetic tissue were sampled in standardized sterile containers. Afterwards, the prosthesis (partial or complete) was removed and placed in sterilized transport containers (Lock\& Lock, Hana Cobi Plastic Co, Ltd., Seoul, Korea) to which $100-500 \mathrm{ml}$ of Ringer's solution was added.

\subsection{Microbiologic evaluation}

The removed orthopaedic material was first vortexed $(30 \mathrm{~s})$ and then subjected to sonication (frequency $40 \mathrm{kHz}$, duration $1 \mathrm{~min}$ ). $50 \mathrm{~mL}$ of sonicate-fluid was then centrifuged (3200 $\mathrm{min}^{-1}$, duration $1 \mathrm{~min}$ ) and sediment cultured on aerobic and anaerobic agar plates (sheep-blood agar, chocolate agar, Schaedler agar) and three liquid media (thyoglycollate broth, BacTalert FA and BacTalert FN, both bioMerieux, France). Cultures were incubated for $14 \mathrm{~d}$ and bacterial growth was assessed quantitatively in colony-forming units per $\mathrm{mL}$ of sonicate-fluid $(\mathrm{CFU} / \mathrm{ml})$. Periprosthetic tissue was homogenized prior to culture on aerobic and anaerobic agar plates and in thyoglycollate broth for $14 \mathrm{~d}$. Bacterial growth was assessed semi-quantitatively ( 0 -absent growth $-3+$ extensive growth).

\subsection{Diagnostic criteria}

The diagnosis of PJI was determined if the following criteria were met: (1) the presence of a sinus tract communicating with the prosthesis, (2) isolation of a single pathogen from two separate samples, (3) isolation of a pathogen from one sample, under the condition that inflammatory parameters were elevated (CRP $>10 \mathrm{mmol} / \mathrm{L}$, ESR $>30 \mathrm{~mm} / \mathrm{h}$ ), (4) isolation of a pathogen from sonicate fluid at a concentration $\geq 50 \mathrm{CFU} / \mathrm{mL}$, (5) isolation of a pathogen from sonicate fluid at a concentration $<50 \mathrm{CFU} / \mathrm{mL}$, under the condition that inflammatory parameters were elevated (CRP $>10 \mathrm{mmol} / \mathrm{L}, \mathrm{ESR}>30 \mathrm{~mm} / \mathrm{h}$ ). In cases of pre-operative antimicrobial therapy, isolation of a pathogen of any number or concentration was considered an infection.

\subsection{Statistical analysis}

Basic demographic and clinical data were analysed using descriptive methods. The sensitivities and specificities of different culture methods were compared using McNemar's test. The impact of antimicrobial therapy on the microbiologic methods was assessed using logistic regression. The results were presented as odds ratios with corresponding $95 \%$ confidence intervals (CI). The limit of statistical significance was at $\alpha=0.05$. The data 
was analysed with the statistical program SPSS 20 (SPSS Inc., Chicago, Illinois, USA) and the R programming language.

\section{RESULTS}

Between November 2010 and December 2013, 103 patients were enrolled in the study. Cumulatively they underwent 136 revision procedures: 105 hip revisions and 31 knee revisions. Forty-one $(39.8 \%)$ patients were males and $62(60.2 \%)$ were females. The average patient age at the time of revision surgery was $65.9 \mathrm{y}( \pm 12.9 \mathrm{y})$. The surgical type distribution is shown in Table $\mathbf{1 .}$

Table 1: Surgical procedure type distribution $(n=136)$

\begin{tabular}{|l|c|}
\hline \multicolumn{1}{|c|}{ Type of surgical procedure } & No. (proportion) \\
\hline mobile parts exchange & $26(19.1 \%)$ \\
\hline one-stage revision & $59(44.7 \%)$ \\
\hline $\begin{array}{l}\text { two-stage revision } \\
\text { (spacer/re-implantation) }\end{array}$ & $38(27.9 \%)$ \\
\hline explantation (Girdlestone) & $10(7.4 \%)$ \\
\hline osteosynthetic material removal & $3(2.2 \%)$ \\
\hline
\end{tabular}

In $31(22.8 \%)$ revision surgery procedures the patient received pre-operative antimicrobial therapy. The average duration of pre-operative antimicrobial therapy was $18.8 \mathrm{~d}( \pm 21.5 \mathrm{~d})$ and the average antimicrobial free interval before surgery was $2.7 \mathrm{~d}( \pm 4.6 \mathrm{~d})$.

Based on pre-operative clinical criteria and postoperative microbiologic results, PJI was diagnosed in 69 $(50.7 \%)$ cases. In $22(16.2 \%)$ cases, micro-organisms were isolated in a single specimen or at a concentration $<50 \mathrm{CFU} / \mathrm{mL}$ of sonicate fluid, which was interpreted as inconclusive and in $45(33.1 \%)$ cases, the culture remained negative and the prosthetic joint failure was determined as aseptic. Among PJI cases, 33 (47.8\%) were classified as early-onset (i.e., <3 months after primary arthroplasty), 17 (24.6\%) were delayed (i.e., 3-24 months after primary arthroplasty) and in 19 $(27.5 \%)$ were late-onset (i.e., >24 months after primary arthroplasty).

Sonicate-fluid cultures and periprosthetic tissue cultures were microbiologically positive (i.e., detection of at least one bacterial species in any culture media) in $79(58.1 \%)$ and $69(50.7 \%)$ cases, respectively. Considering the diagnostic criteria for PJI, sonicate-fluid culture was diagnostic in $57(82.6 \%)$ cases, of which 12 $(21.1 \%)$ cases were periprosthetic tissue culture negative. Periprosthetic tissue culture was diagnostic in $52(75.4 \%)$ cases, of which $7(13.5 \%)$ cases were sonicate-fluid culture negative. In $45(65.2 \%)$ cases the infection was diagnosed by both methods and in 4 $(5.8 \%)$ cases the diagnosis of PJI was made based on both methods, whereas if considering a single method independently, the result was inconclusive. In 1 (1.4\%) case, both methods failed to isolate a micro-organism even though clinical criteria were sufficient to diagnose
PJI and the patient had sinus tract, elevated CRP concentration and ESR. However, the patient received pre-operative antimicrobial therapy.

Among 31 procedures where patients received pre-operative antimicrobial therapy sonicate-fluid culture and periprosthetic tissue cultures were diagnostic in 26 $(83.9 \%)$ and $22(71.0 \%)$ of cases, respectively. Both methods failed to isolate the pathogen in $1(3.2 \%)$ case. According to the diagnostic criteria, the isolation of any amount of micro-organism is considered diagnostic for $\mathrm{PJI}$ in the case of pre-operative antimicrobial therapy.

Sonicate-fluid culture was monomicrobial (i.e., single microorganism isolated) in $38(66.7 \%)$ cases and polymicrobial (i.e., $>1$ microorganism isolated) in 19 $(33.3 \%)$ cases. On the other hand, periprosthetic tissue culture was monomicrobial in $24(46.2 \%)$ cases and polymicrobial in $28(53.9 \%)$ cases. The distribution of microorganisms isolated by both methods is shown in Table 2.

Table 2: Distribution of micro-organism detected by both sonicate fluid and periprosthetic tissue cultures (monomicrobial samples)

\begin{tabular}{|l|c|}
\hline \multicolumn{1}{|c|}{ Sonicate fluid } & No. (proportion) \\
\hline Coagulase-negative staphylococci & $16(28.1 \%)$ \\
\hline Staphylococcus aureus & $10(17.5 \%)$ \\
\hline Burkholderia cepacia & $3(5.3 \%)$ \\
\hline Cutibacterium acnes & $3(5.3 \%)$ \\
\hline Streptococcus spp. & $3(5.3 \%)$ \\
\hline Escherichia coli & $1(1.8 \%)$ \\
\hline Enterococcus faecium & $1(1.8 \%)$ \\
\hline Klebsiella pneumoniae & $1(1.8 \%)$ \\
\hline \multicolumn{1}{|c|}{ Periprosthetic tissue culture } & No. (proportion) \\
\hline Coagulase-negative staphylococci & $8(15.4 \%)$ \\
\hline Staphylococcus aureus & $6(11.5 \%)$ \\
\hline Cutibacterium acnes & $5(9.6 \%)$ \\
\hline Streptococcus spp. & $2(3.8 \%)$ \\
\hline Enterococcus faecium & $1(1.9 \%)$ \\
\hline Klebsiella pneumoniae & $1(1.9 \%)$ \\
\hline Lactobacillus rhamnosus & $1(1.9 \%)$ \\
\hline
\end{tabular}

In a logistic regression model, sonicate-fluid culture of explanted orthopaedic material has proven to be superior to periprosthetic tissue culture for the detection of PJI in the case of pre-operative antimicrobial therapy $(\mathrm{OR}=0.01,95 \% \mathrm{CI}:<0.01-0.26, \mathrm{p}=0.005)$. In case of no pre-operative antimicrobial therapy, there was no significant difference in the PJI detection rate by both methods (OR $=0.76,95 \% \mathrm{CI}: 0.02-25.22, \mathrm{p}=0.938)$.

Overall, there was no significant difference in the detection of PJI using sonicate-fluid culture (41.9\%) and periprosthetic tissue culture $(38.2 \%)$ using McNemar's test $(\mathrm{p}=0.264)$.

The analysis of pre-operative laboratory parameters using a ROC curve has shown that the ideal cut-off value of CRP for the detection of infection is $11 \mathrm{mmol} / \mathrm{L}$ (77.2\% sensitivity, and $83.5 \%$ specificity) for the analysis using sonicate-fluid culture and $12 \mathrm{mmol} / \mathrm{L}$ for the analysis of periprosthetic tissue culture $(80.4 \%$ 
sensitivity and $84.7 \%$ specificity). The ideal cut-off value of pre-operative $\mathrm{SR}$ is $25 \mathrm{~mm} / \mathrm{h}$ for the analysis using sonicate-fluid culture $(73.7 \%$ sensitivity and $68.4 \%$ specificity) and $32 \mathrm{~mm} / \mathrm{h}(72.6 \%$ sensitivity and $78.8 \%$ specificity) for the analysis using periprosthetic tissue culture.

The pre-operative value of CRP is a better predictor of PJI using periprosthetic tissue culture analysis than using sonicate-fluid culture analysis, $\mathrm{AUC}=0.78(95 \%$ CI: 0.69-0.87) versus AUC $=0.74$ (95\% CI: 0.65-0.82), respectively. Furthermore, ESR is also a better predictor of PJI using periprosthetic tissue culture analysis than using sonicate-fluid culture analysis, $\mathrm{AUC}=0.87(95 \%$ CI: 0.81-0.94) versus AUC $=0.84$ (95\% CI: 0.77-0.91), respectively.

\section{DISCUSSION}

The purpose of the study was to evaluate the use of sonication as an additional diagnostic tool for the detection of PJI, with the emphasis on patients receiving pre-operative antimicrobial therapy. We have predicted that the sonicate-fluid culture of explanted orthopaedic material obtained during revision surgery of prosthetic joint failure will be superior compared to periprosthetic tissue culture in the isolation of causative micro-organisms and the detection of PJI.

The obtained results have shown that in cases where the patients received pre-operative antimicrobial therapy, sonication was superior compared to periprosthetic tissue culture. Pre-operative antimicrobial therapy is a risk factor for culture-negative prosthetic joint infection. ${ }^{18,19}$ In our study, one case of PJI remained culture-negative and the antimicrobial therapy was introduced on an empirical basis. Similar results were obtained in previous studies, emphasizing the importance of sonication in the cases of pre-operative antimicrobial therapy. ${ }^{8}$ Pre-operative antimicrobial therapy can jeopardize the pathogen isolation; therefore, antimicrobial therapy is selected empirically, which is suboptimal.

On the other hand, sonication of explanted orthopaedic material in the absence of pre-operative antimicrobial therapy did not show a significant improvement of the detection of PJI. These results are not concordant with previously published studies, where the sonication of explanted material has shown a superior diagnostic value. ${ }^{8,20-22}$ The discrepancy of results could reflect different diagnostic criteria for PJI used among studies. At our institution the isolation of low-virulent microorganisms, especially Coagulase-negative staphylococci (CNS) and Cutibacterium acnes, are considered highly suspicious for PJI and additional criteria should be evaluated. Isolation of a pathogen in a single sample or isolation in a concentration of $<50 \mathrm{CFU} / \mathrm{mL}$ with the presence of elevated inflammatory parameters should be considered as PJI, if other causes of elevated CRP value and ESR are excluded. Because of the moderate accuracy of intraoperative periprosthetic frozen section histologic evaluation, it is not performed routinely at our facility. ${ }^{23}$

In our study, a large proportion of both sonicate-fluid and periprosthetic tissue cultures were polymicrobial, $33.3 \%$ and $53.9 \%$, respectively. Compared to other authors that have reported much lower proportions of polymicrobial cultures of $10-11 \%, 8,24$ these proportions were surprising. However, the latest research on biofilm formation and structure has led to new insights into polymicrobial growth with a diverse bacterial composition. ${ }^{25}$ In a recent study, polymicrobial biofilm formation was detected in 9/14 PJI cases using the 16S rRNA gene PCR, compared to $1 / 10$ polymicrobial samples using conventional diagnostic methods. ${ }^{26}$ Accordingly, monomicrobial samples isolated from PJI are most probably a consequence of an inadequate sampling and cultivation, as only certain bacteria have optimal conditions for growth. In our study, the incubation period was 14 days for both aerobic and anaerobic cultures, allowing even most fastidious bacteria enough time to grow. The other possible explanation of the high ratio of polymicrobial infection is also the contamination of samples, which can occur during the entire process of sampling, transport and cultivation.

The analysis of cut-off values for pre-operative CRP concentration and ESR using ROC analysis has revealed that the ideal cut-off values are lower in the case of infection detection using sonication than periprosthetic tissue cultures. The proposed and widely accepted cut-off value for the detection of PJI is CRP concentration of $10 \mathrm{mmol} / \mathrm{L}$ and ESR of $30 \mathrm{~mm} / \mathrm{h}$, which was also acknowledged by the Workgroup of the Musculoskeletal Infection Society and was used also in the present study. ${ }^{27}$ In a recent study, the diagnostic cut-off value of pre-operative CRP concentration and ESR were set to $20.5 \mathrm{mg} / \mathrm{L}$ and $31 \mathrm{~mm} / \mathrm{h}$, respectively. ${ }^{28}$ These values are significantly higher than our results and most probably reflect the lack of sonication, but also different diagnostic criteria for the evaluation of PJI. In another study, lower cut-off values were considered to be optimal for the detection of PJI: $14.5 \mathrm{mg} / \mathrm{L}$ and $10.3 \mathrm{mg} / \mathrm{L}$ for CRP and $19 \mathrm{~mm} / \mathrm{h}$ and $13 \mathrm{~mm} / \mathrm{h}$ for ESR, for knee and hip infection, respectively. ${ }^{29}$

The main benefit of our study is a recognition that sonicate-fluid cultures perform significantly better than periprosthetic tissue cultures in a clinical setting where pre-operative antimicrobial therapy was used and therefore enabling guided antimicrobial therapy. Accurate detection of the causative micro-organism reduces the risk of revision surgery because of the missed PJI. The study has also shown that an adequate number of periprosthetic tissue samples is sufficient for the detection of PJI in patients without pre-operative antimicrobial therapy.

The main limitation of the study is a lack of polymerase chain reaction (PCR) analysis of the sonicate 


\section{B. KOCJANČIČ et al.: THE IMPORTANCE OF SONICATION AND PRE-OPERATIVE ANTIMICROBIAL THERAPY}

samples. Furthermore, pre-operative diagnostic aspiration of synovial fluid was not regularly performed at our institution; therefore, the method was not included in the study.

\section{CONCLUSIONS}

Sonicate-fluid cultures of explanted orthopaedic material represent an important tool for the accurate detection of a pathogen in cases of pre-operative antimicrobial therapy. It is crucial for the detection of the pathogen and the introduction of guided antimicrobial therapy. Nonetheless, despite accurate pre-operative assessment, meticulous tissue and material sampling and microbiologic analysis, culture-negative PJI remains a serious problem. In patients who did not receive pre-operative antimicrobials, a thorough pre-operative assessment and an adequate number of periprosthetic tissue samples could be sufficient for the detection of PJI.

\section{REFERENCES}

${ }^{1}$ S. Kurtz, K. Ong, E. Lau, F. Mowat, M. Halpern,Projections of primary and revision hip and knee arthroplasty in the United States from 2005 to 2030, J. Bone Joint Surg. (Am), 89 (2007) 4, 780-785, doi: 10.2106/JBJS.F.00222

${ }^{2}$ H. Malchau, P. Herberts, T. Eisler, G. Garellick, P. Söderman, The Swedish total hip replacement register, J. Bone Joint Surg. (Am), Suppl. 2,) 84 (2002), 2-20, doi:10.2106/00004623-20020000200002

${ }^{3}$ W. Zimmerli, A. Trampuz, P. E. Ochsner, Prosthetic-joint infections, N. Engl. J. Med. 351 (2004) 16, 1645-1654, doi:10.1056/ NEJMra040181

${ }^{4}$ R. O. Darouiche, Device-associated infections: A macroproblem that starts with microadherence, Clin. Infect. Dis., 33 (2001) 9, 1567-1572, doi:10.1086/323130

${ }^{5}$ R. M. Donlan, J.W. Costerton, Biofilms: survival mechanisms of clinically relevant microorganisms, Clin. Microbiol. Rev., 15 (2002) 2, 167-193, doi:10.1128/cmr.15.2.167-193.2002

${ }^{6}$ M. M. Tunney, S. Patrick, S. P. Gorman, J. R. Nixon, N. Anderson, R. I. Davis, D. Hanna, G. Ramage, Improved detection of infection in hip replacements. A currently underestimated problem, J. Bone Joint. Surg. (Br.), 80 (1998) 4, 568-572, doi:10.1302/0301620x.80b4.8473

${ }^{7}$ N. Kobayashi, TW. Bauer, MJ. Tuohy, T. Fujishiro, GW. Procop: Brief ultrasonication improves detection of biofilm-formative bacteria around a metal implant, Clin Orthop Relat Res 457 (2007) 210-213, doi:10.1097/BLO.0b013e3180312042

${ }^{8}$ A. Trampuz, K. E. Piper, M. J. Jacobson, A. D. Hanssen, K. K Unni, D. R. Osmon, J. N. Mandrekar, F. R. Cockerill, J. M. Steckelberg, J. F. Greenleaf, R. Patel, Sonication of removed hip and knee prostheses for diagnosis of infection, N. Engl. J. Med., 357 (2007) 7, 654-663, doi:10.1056/NEJMoa061588

${ }^{9}$ Y. Achermann, M. Vogt, M. Leunig, J. Wüst, A. Trampuz, Improved diagnosis of periprosthetic joint infection by multiplex PCR of sonication fluid from removed implants, J. Clin. Microbiol., 48 (2010) 4, 1208-1214, doi:10.1128/JCM.00006-10

${ }^{10}$ M. E. Portillo, M. Salvadó, L. Sorli, A. Alier, S. Martínez, A. Trampuz, J. Gómez, L. Puig, J. P. Horcajada, Multiplex PCR of sonication fluid accurately differentiates between prosthetic joint infection and aseptic failure, J. Infect. 65 (2012) 6, 541-548, doi:10.1016/j.jinf. 2012.08.018
${ }^{11}$ C. L. Nelson, A. C. McLaren, S. G. McLaren, J. W. Johnson, M. S., Is aseptic loosening truly aseptic?, Clin. Orthop. Relat. Res., 437 (2005) 25-30, doi:10.1097/01.blo.0000175715.68624.3d

${ }^{12}$ D. J. Moojen, G. van Hellemondt, H. C. Vogely, B. J. Burger, G. H. I. M. Walenkamp, N. J. A. Tulp, B. W Schreurs, F. R. A. J. de Meulemeester, C. S. Schot, I. van de Pol, T. Fujishiro, L. M. Schouls, T. W. Bauer, W. J. A. Dhert, Incidence of low-grade infection in aseptic loosening of total hip arthroplasty, Acta Orthop., 81 (2010) 6, 667-673, doi:10.3109/17453674.2010.525201

${ }^{13}$ E. F. Berbari, C. Marculescu, I. Sia, B. D. Lahr, A. D. Hanssen, J. M. Steckelberg, R. Gullerud, D. R., Culture-negative prosthetic joint infection, Clin. Infect. Dis., 45 (2007) 9, 1113-1119, doi:10.1086/ 522184

${ }^{14}$ J. M. Sierra, S. García, J. C. Martínez-Pastor, X. Tomás, X. Gallart, J. Vila, G. Bori, F. Maculé, J. Mensa, J. Riba, A. Soriano, Relationship between the degree of osteolysis and cultures obtained by sonication of the prostheses in patients with aseptic loosening of a hip or knee arthroplasty, Arch Orthop. Trauma Surg., 131 (2011) 10, 1357-1361, doi:10.1007/s00402-011-1307-4

${ }^{15}$ J. Parvizi, C. J. Della Valle, AAOS Clinical Practice Guideline: diagnosis and treatment of periprosthetic joint infections of the hip and knee, J. Am. Acad. Orthop. Surg., 18 (2010) 12, 771-772

${ }^{16}$ J. Parvizi, B. Zmistowski, E. F. Berbari, T. W. Bauer, B. D. Springer, C. J. Della Valle, K. L. Garvin, M. A. Mont, M. D. Wongworawat, C. G. Zalavras: New definition for periprosthetic joint infection: from the Workgroup of the Musculoskeletal Infection Society, Clin. Orthop. Relat. Res., 469 (2011) 11, 2992-2994, doi:10.1007/s11999-011-2102-9

${ }^{17}$ D. R. Osmon, E. F. Berbari, A. R. Berendt, D. Lew, W. Zimmerli, J. M. Steckelberg, N. Rao, A. Hanssen, W. R. Wilson, Executive summary: diagnosis and management of prosthetic joint infection: clinical practice guidelines by the infectious diseases society of America, Clin. Infect. Dis., 56 (2013) 1, 1-10, doi:10.1093/ $\mathrm{cid} / \mathrm{cis} 803$

${ }^{18}$ D. Malekzadeh, D. R. Osmon, B. D. Lahr, A. D. Hanssen, E. F. Berbari, Prior use of antimicrobial therapy is a risk factor for culture-negative prosthetic joint infection, Clin. Orthop. Relat. Res., 468 (2010) 8, 2039-2045, doi:10.1007/s11999-010-1338-0

${ }^{19}$ E. F. Berbari, C. Marculescu, I. Sia, B. D. Lahr, A. D. Hanssen, J. M. Steckelberg, R. Gullerud, D.R. Osmon, Culture-negative prosthetic joint infection, Clin. Infect. Dis., 45 (2007) 9, 1113-1119, doi:10.1086/522184

${ }^{20}$ M. E. Portillo, M. Salvadó, A. Alier, S. Martínez, L. Sorli, J. P. Horcajada, L. Puig, Advantages of sonication fluid culture for the diagnosis of prosthetic joint infection, J. Infect., 69 (2014) 1, 35-41, doi: $10.1016 /$ j.jinf.2014.03.002

${ }^{21}$ K. E. Piper, M. J. Jacobson, R. H. Cofield, J. W. Sperling, J. Sanchez-Sotelo, D. R. Osmon, A. McDowell, S. Patrick, J. M. Steckelberg, J. N. Mandrekar, M. Fernandez Sampedro, R. Patel, Microbiologic diagnosis of prosthetic shoulder infection by use of implant sonication, J. Clin. Microbiol., 47 (2009) 6, 1878-1884, doi:10.1128/JCM.01686-08

${ }^{22}$ J. Holinka, L. Bauer, A. M. Hirschl, W. Graninger, R. Windhager, E. Presterl, Sonication cultures of explanted components as an add-on test to routinely conducted microbiological diagnostics improve pathogen detection, J. Orthop. Res., 29 (2011) 4, 617-622, doi:10.1002/jor.21286

${ }^{23}$ G. Tsaras, A. Maduka-Ezeh, C. Y. Inwards, T. Mabry, P. J. Erwin, M. H. Murad, V. M. Montori, C. P. West, D. R. Osmon, E. F. Berbari, Utility of intraoperative frozen section histopathology in the diagnosis of periprosthetic joint infection: a systematic review and meta-analysis, J. Bone Joint Surg. (Am), 94 (2012) 18, 1700-1711, doi: 10.2106/JBJS.J.00756

${ }^{24}$ A. Trampuz, W. Zimmerli, Prosthetic joint infections: update in diagnosis and treatment, Swiss Med. Wkly., 135 (2005) 243-251, doi: 2005/17/smw-10934 


\section{B. KOCJANČIČ et al.: THE IMPORTANCE OF SONICATION AND PRE-OPERATIVE ANTIMICROBIAL THERAPY}

${ }^{25}$ R. Wolcott, J. W. Costerton, D. Raoult, S. J. Cutler, The polymicrobial nature of biofilm infection, Clin. Microbiol. Infect., 19 (2013) 2, 107-112, doi:10.1111/j.1469-0691.2012.04001.x

${ }^{26}$ Y. Xu, V. B. Rudkjøbing, O. Simonsen, C. Pedersen, J. Lorenzen, H. C. Schønheyder, P. H. Nielsen, T. R. Thomsen, Bacterial diversity in suspected prosthetic joint infections: an exploratory study using $16 \mathrm{~S}$ rRNA gene analysis, FEMS Immunol. Med. Microbiol., 65 (2012) 2, 291-304, doi:10.1111/j.1574-695X.2012.00949.x

${ }^{27}$ M. F. Schinsky, C. J. Della Valle, S. M. Sporer, W.G. Paprosky, Perioperative testing for joint infection in patients undergoing revision total hip arthroplasty, J. Bone Joint Surg. (Am), 90 (2008) 9, 1869-1875, doi:10.2106/JBJS.G.01255
${ }^{28}$ E. Ghanem, V. Jr. Antoci, L. Pulido, A. Joshi, W. Hozack, J. Parvizi,The use of receiver operating characteristics analysis in determining erythrocyte sedimentation rate and C-reactive protein levels in diagnosing periprosthetic infection prior to revision total hip arthroplasty, Int. J. Infect. Dis., 13 (2009) 6, 444-449, doi:10.1016/j.ijid.2009.02.017

${ }^{29}$ K. E. Piper, M. Fernandez-Sampedro, K. E. Steckelberg, J. N. Mandrekar, M. J. Karau, J. M. Steckelberg, E. F. Berbari, D. R. Osmon, A. D. Hanssen, D. G. Lewallen, R. H. Cofield, J. W. Sperling, J. Sanchez-Sotelo, P. M. Huddleston, M. B. Dekutoski, M. Yaszemski, B. Currier, R. Patel, C-Reactive Protein, Erythrocyte Sedimentation Rate and Orthopedic Implant Infection, PLoS One 5 (2010) 2, 9358, doi:10.1371/journal.pone.0009358 